\title{
Efficiency of Particle Retention and Filtration Rate in Four Species of Ascidians
}

\author{
A. Randløv and H. U. Riisgård \\ Marine Pollution Laboratory, National Agency of Environmental Protection, Kavalergården 6, DK-2920 Charlottenlund, \\ Denmark
}

\begin{abstract}
Particle retention in Ascidiella aspersa, Molgula manhattensis, Clavelina lepadiformis and Ciona intestinalis was determined from comparisons of particle-size distributions in the inhaled and exhaled water. Particles down to 2-3 $\mu \mathrm{m}$ were completely retained and the retention efficiency of smaller particles decreased to about $70 \%$ for $1 \mu \mathrm{m}$ particles. There was no indication that the ascidians were able to adjust their retention efficiency. Filtration rates $\left(F, \mathrm{ml} \mathrm{min}^{-1}\right)$ as a function of total dry weight ( $W_{\text {lotal }} g$ ) could be expressed as $F=54.4 W_{\text {total }}^{1.05}$ in $A$. aspersa and $F=46.4 W_{\text {total }}^{0.84}$ in $C$. intestinalis. It is concluded that undisturbed ascidians filter the water continuously at constant rates.
\end{abstract}

\section{INTRODUCTION}

The amount of food (i. e. suspended organic particles in the surrounding water) available to suspensionfeeding ascidians is determined by the amount of water transported through the branchial basket and by the efficiency with which the particles are retained by the mucous filter covering the inner wall of the pharynx.

The filtration rate in ascidians has been measured by several early investigators using different techniques as reviewed by Jørgensen (1966). More recently, filtration rates have been measured by Holmes (1973) and Fiala-Médioni $(1973,1974,1978$ a, b, c), but consistent and unambiguous results have not been obtained

Retention efficiency in ascidians has been measured by Jørgensen (1949, 1952), Jørgensen and Goldberg (1953) and Goldberg et al. (1951), who found that Ciona intestinalis and Molgula manhattensis effectively retain graphite particles down to about $1 \mu \mathrm{m}$ while retention of blood proteins is low. Recently, however, Fiala-Médioni (1978b) has reported on inefficient retention of even $6-10 \times 2-3 \mu \mathrm{m}$ algal cells in $C$. intestinalis, Phallusia mammillata, and Styela plicata.

In the present study the technique developed by Møhlenberg and Riisgård (1979) for measuring filtration rates and retention efficiencies (Møhlenberg and Riisgård, 1978) in undisturbed suspension-feeding

\footnotetext{
- For the most recent contribution by Fiala-Médioni consult p. 49 of this volume of 'Mar. Ecol. Prog. Ser.'.
}

bivalves has been applied to ascidians. The present paper reports on retention efficiency and filtration rate in four species of ascidians.

\section{MATERIALS AND METHODS}

The experiments were conducted in July and August 1978 at the Marine Biological Station, Rønbjerg, Denmark, and in September 1978 at the Marine Biological Laboratory, Helsingør, Denmark.

Molgula manhattensis (De Kay), Ascidiella aspersa (O. F. Müller), Clavelina lepadiformis (O. F. Müller) were collected by hand in the Limfjord: $M$. manhattensis near the Biological Station, Rønbjerg, at a depth of $3 \mathrm{~m}$, attached to stones on which they were brought to the laboratory; $A$. aspersa from Kaas Bredning at a depth of $1 \mathrm{~m}$, attached to plant debris, and $C$. lepadiformis from Lysen Bredning, at a depth of about $3 \mathrm{~m}$ on the seaweed Fucus bulbosus.

In the laboratory at Rønbjerg the ascidians were placed in aquaria of 301 in flowing sea water, pumped into the laboratory from an $8 \mathrm{~m}$ depth in the fjord. The animals were allowed to acclimate 1-7 days to the laboratory conditions $\left(20^{\circ} \mathrm{C}\right.$ and $25 \%$ S) before the experiments were performed.

Ciona intestinalis (L.) were collected by diving in the Kattegat near the Biological Station, Kristineberg, Sweden, at a depth of $10 \mathrm{~m}\left(10^{\circ} \mathrm{C}\right.$ and $\left.29 \% \mathrm{~S}\right)$ and brought to the Marine Biological Laboratory, Helsingør. The animals acclimated $2-14$ days $\left(10^{\prime} \mathrm{C}\right.$ and 
$27 \%$ S) in aquaria of $30 \mathrm{l}$ with aerated sea water, and the water was changed every second day.

In the laboratory the ascidians were continuously pumping and did not visibly respond to addition of algae as judged from their permanently open inhalant and exhalant apertures and distended siphons. Only when disturbed were the apertures more or less closed and, eventually, the siphons retracted.
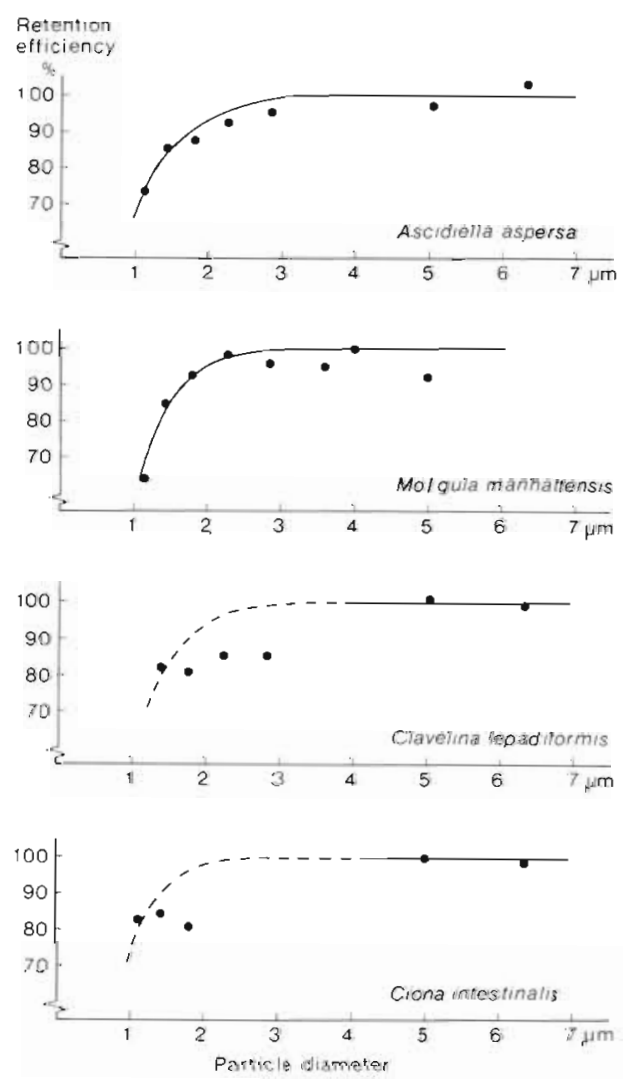

Fig. 1. Retention as a function of particle size in four ascidians. Each value is the mean of 4-6 measurements

The particles used for measuring retention efficiency were those occurring in the sea water system (mainly small particles) to which were added the marine flagellates Monochrysis lutheri and Dunaliella marina grown in monocultures in enriched $28 \%$ S sea water, so that a particle spectrum from 1 to about $7 \mu \mathrm{m}$ was covered (see Møhlenberg and Riisgård, 1978; their Fig. 1). The algae were chosen because of their nearly spherical shape (oviform) so that the diameter measured by the electronic particle counter was reliable.

Dunaliella marina was used for measuring filtration rates because it is completely retained by the ascidians (see later). Suspensions of the flagellate were added to the experimental aquaria to make initial concentrations of about 10000 cells $\mathrm{ml}^{-1}$.

Retention efficiency of particles of different sizes was determined according to Møhlenberg and Riisgård (1978): Samples of inhaled and exhaled water were collected simultaneously by means of two glass tubes (internal diameter $=0.5$ or $0.3 \mathrm{~cm}$ ) the openings of which were placed about $0.5 \mathrm{~cm}$ from the inhalant and exhalant apertures. The tube collecting exhaled water was mounted with a fitting at least twice as wide as the exhalant aperture (Møhlenberg and Risgård,

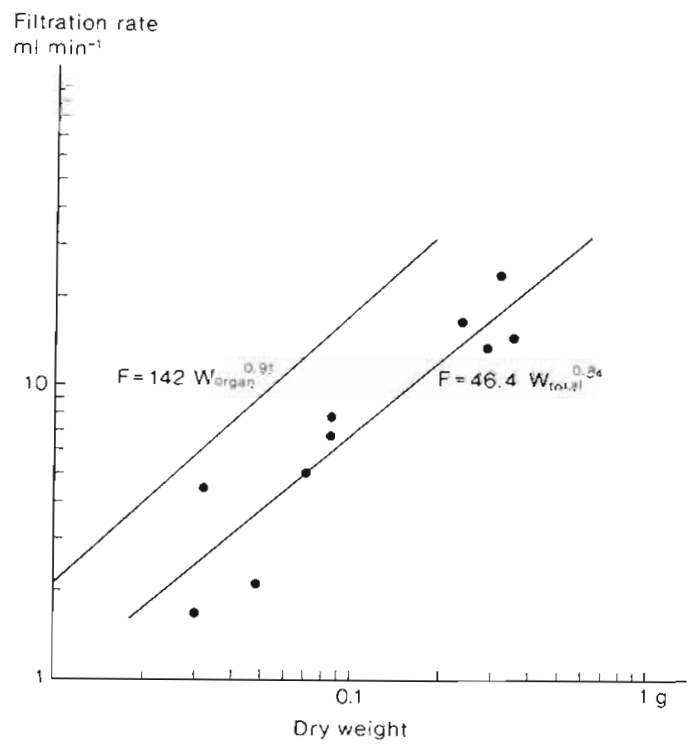

Fig. 2. Ciona intestinalis. Filtration rate at $10^{\circ} \mathrm{C}$ as a function of total dry weight ( $\left.W_{\text {toca }}\right)$. Regression line and equation for the line are shown. Line showing filtration rate as a function of dry weight of the soft tissue ( $W_{\text {organ }}$ ) and equation for the line are also indicated

1978; their Fig. 2). At sufficiently low flow rates the collected exhaled water exclusively consisted of filtered water and the fraction retained of particles of different sizes could be calculated as $1-\frac{C_{e}}{C_{j}}$, where $c_{e}$ and $c_{i}$ are the concentrations of a certain particle size in the exhaled and inhaled water, respectively.

Filtration rates (C) were determined according to the formula:

$$
C=F_{c}\left(1-\frac{C_{e}}{C_{i}}\right)
$$

where $F_{c}$ is the flow rate in the two glass tubes (which was always adjusted to the same rate by means of clamping screws on the plastic tubes connecting the glass tubes and the sample beakers). To determine the filtration rate from the formula the 'geometry' of the set-up had to be checked and the flow rate adjusted as previously described (Riisgărd, 1977; Møhlenberg and Riisgård, 1979).

The two methods only worked satisfactorily on ascidians heavier than a few $m$, and the filtration rate and retention efficiency in smaller individuals were therefore determined from the rates (C) by which particles of 
different sizes were cleared from suspensions by means of the formula

$$
C=\frac{M}{t} \ln \frac{C_{0}}{C_{1}}
$$

where $M$ is volume of suspension, $t$ time, $c_{0}$ and $c_{t}$ particle concentration at time $o$ and time $t$ (Coughlan, 1969). Two experiments were performed on Clavelina lepadiformis using 240 individuals (mean dry weight $0.75 \mathrm{mg}$ ) and 640 individuals (mean dry weight $0.50 \mathrm{mg}$ ), settled on vertically stretched thalli of Fucus bulbosus while an electric motor stirrer ensured appropriate mixing of the water in the experimental beaker. Samples for particle analysis were taken in the water column by means of a pipette $(40 \mathrm{ml})$. The filtration rate was identical to the clearance of $100 \%$ retained particles (larger than $4 \mu \mathrm{m}$ ), and the retention efficiency spectrum was achieved by expressing the clearances of smaller particles relative to filtration rate.

The concentration of the different-sized particles was determined with an electronic particle counter, Coulter Counter, Model TA II, with a population accessory plotter and a $50 \mu \mathrm{m}$ tube orifice diameter.

After each experiment the total dry weight of the animals was determined. 21 individuals of Ciona intestinalis and 13 individuals of Ascidiella aspersa were separated in test (tunica) and soft tissue to establish the dry weight relationship between these parts of the animal. The dry weight of the test ( $W_{\text {test }}, g$ ) as a function of total dry weight ( $W_{\text {total }}$ g) could be expressed as $W_{\text {test }}=0.448 W_{\text {total }}{ }^{086}\left(r^{2}=0.99\right)$ in $A$. aspersa and $W_{\text {lest }}=0.689 W_{\text {total }}^{1.04}\left(r^{2}=0.99\right)$ in C. intestinalis.

The total nitrogen content in test and soft tissue in 2 Ciona intestinalis was determined on a Perkin Elmer CHN-analyzer, Model 240. Expressed as fractions of dry weight ( \pm S. D.) the nitrogen content was $3.9 \%$ $( \pm 0.7)$ for the whole animal, $2.0 \%( \pm 0.6)$ for the test, and $8.8 \%( \pm 1.0)$ for the soft tissue.

\section{RESULTS}

The efficiency with which particles of different sizes were strained from the water pumped through the branchial basket of Ascidiella aspersa, Molgula manhattensis, Clavelina lepadiformis and Ciona intestinalis is shown in Figure 1. A. aspersa and M. manhattensis completely retained particles down to about 2-3 $\mu \mathrm{m}$ in diameter below which the retention efficiency gradually decreased to about $70 \%$ for $1 \mu \mathrm{m}$ particles. As indicated by the dotted lines in the graphs showing the retention in $C$. lepadiformis and $C$. intestinalis more measurements in the particle-size range 2-5 $\mu \mathrm{m}$ would probably give the same retention spec- trum as found for the two above-mentioned species. The precision of the retention measurements was less than $4 \% \mathrm{~S}$. D. of the arithmetic means for particles above $4 \mu \mathrm{m}$ increasing up to $26 \% \mathrm{~S}$. D. for 1 ..m particles (Møhlenberg and Riisgård, 1978).

Figures 2 and 3 show the filtration rate $\left(F, \mathrm{ml} \mathrm{min}^{-1}\right)$ in Ciona intestinalis and Ascidiella aspersa as a function of their total dry weight ( $W_{\text {total }} g$ ) in a double logarithmic plot. The filtration rate can, by linear

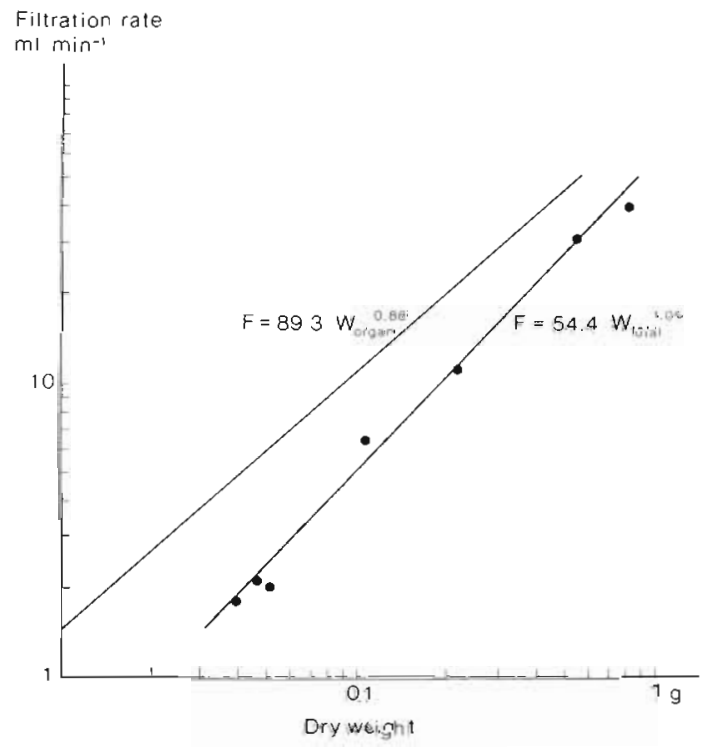

Fig. 3. Ascidiella aspersa. Filtration rate at $20^{\circ} \mathrm{C}$ as a function of total dry weight (see legend to Fig. 1)

regression analysis of the log-log transformed values, be expressed by the allometric equation: $F=a W^{b}$, where $b$ is the slope of the regression line and $a$ the filtration rate of a $1 \mathrm{~g}$ animal. The filtration rates are expressed as $F=46.4 W_{\text {total }}^{0.84}\left(r^{2}=0.85\right)$ in $C$. intestinalis and $F=54.4 W_{\text {total }}^{1.05}\left(r^{2}=0.99\right)$ in $A$. aspersa. In Figures 2 and 3 are also shown the $-\circ$ line and the equations for filtration rate as a function of the dry weight of the soft tissue ( $W_{\text {organ }} g$ ) obtained as the difference between total dry weight and weight of the test.

Figure 4 shows filtration rates measured in Molgula manhattensis and Clavelina lepadiformis as a function of total dry weight. Data from the literature and the regression lines for Ciona intestinalis and Ascidiella aspersa have been inserted for comparison.

\section{DISCUSSION}

The straining of particles from the feeding current in ascidians is performed by a mucous filter produced by the endostyle (Werner and Werner, 1954). In Ciona intestinalis and Molgula manhattensis the filter 


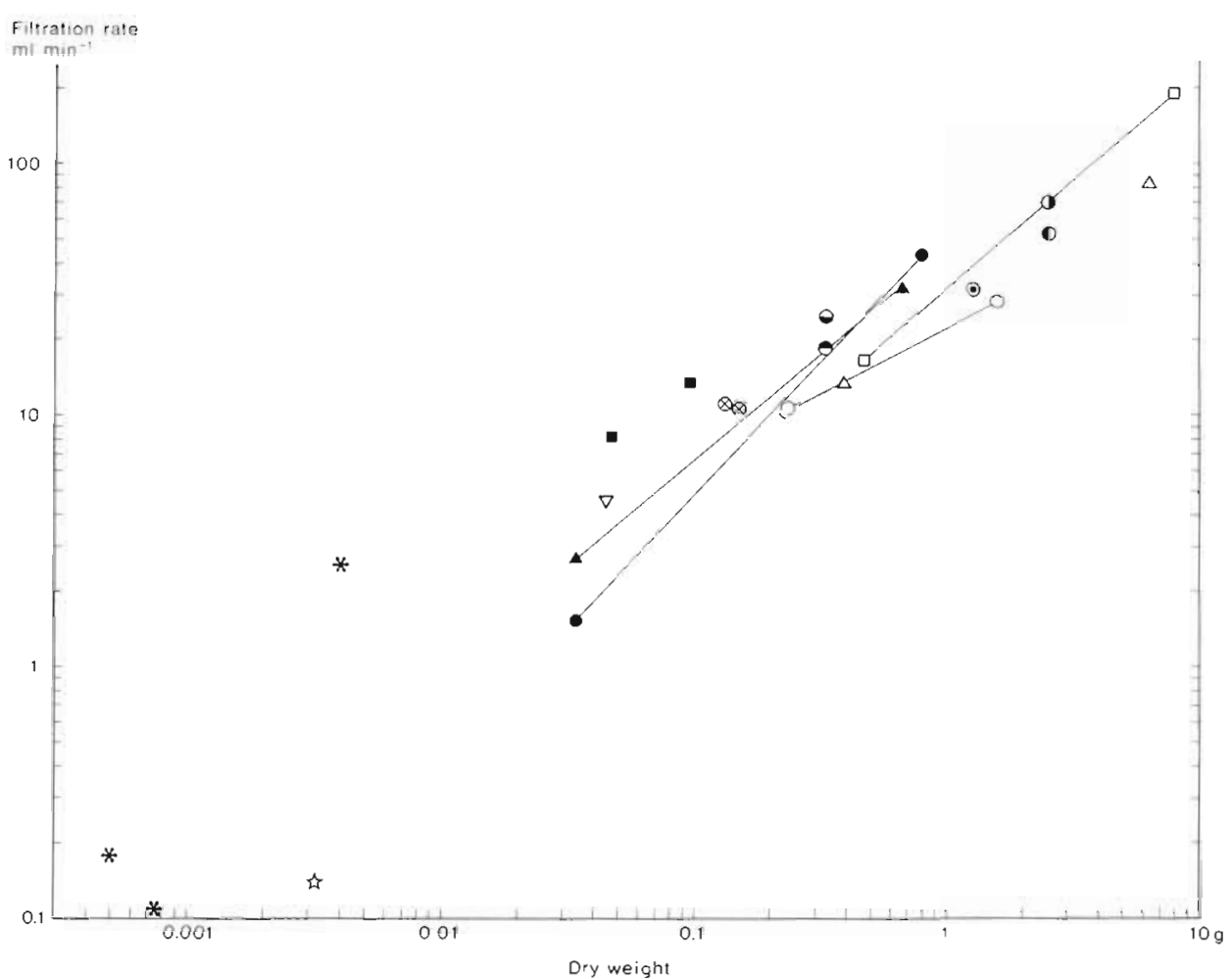

Fig. 4. Relationship between total dry weight and filtration rate in ascidians measured by different techniques under various conditions. Ciona intestinalis: $\triangle$ present work $\left(10^{\circ} \mathrm{C}\right) ; \otimes$ Jørgensen, $1949\left({ }^{\circ} \mathrm{C}\right) ; \bullet \bullet, / \mathrm{I}$ Fiala-Médioni, $1978 \mathrm{~b}\left(15^{\circ} \mathrm{C}\right) ; \odot \mathrm{Goldberg}$ et al., $1951\left(12^{\circ} \mathrm{C}\right)$. Molgula manhattensis: - present work $\left(20^{\circ} \mathrm{C}\right)$; Molgulasp: $\nabla$ Jørgensen 1949 (? ' $\left.\mathrm{C}\right)$; Clavelina lepadiformis: ¿ Fiala-Médioni, $1974\left(15^{\circ} \mathrm{C}\right)$; * present work $\left(20^{\circ} \mathrm{C}\right)$. Ascidia atra: a Hecht, $1916\left(15^{\circ} \mathrm{C}\right)$. Ascidiella aspersa: - present work $\left(20^{\circ} \mathrm{C}\right)$; O Holmes, $1973\left(18^{\circ} \mathrm{C}\right)$. Phallusia mammillata: $\triangle$ Carlisle, $1966\left(15^{\circ} \mathrm{C}\right) ; 0$, Fiala-Médioni, 1978 d $\left(15^{\circ} \mathrm{C}\right)$. (Total dry weight $=5 \%$ of total wet weight, and nitrogen content $=4 \%$ of total dry weight, has been used for estimating total dry weight when these figures had not been given by authors)

retained efficiently 1-2 $\mu \mathrm{m}$ graphite particles (Jørgensen, 1952; Jørgensen and Goldberg, 1953). This agrees with our own finding in the same two species and in Ascidiella aspersa and Clavelina lepadiformis. But recently Fiala-Médioni (1978b) concluded that in $C$. intestinalis and in other ascidians up to one third of $6-10 \times 2-3 \mu \mathrm{m}$ algal cells passed through the branchial basket. This conclusion was based on the finding that pumping rates, as determined by a thermistor technique, were larger than filtration rates calculated from the rates at which the ascidians cleared suspensions of Monochrysis lutheri. However, the technique used to measure clearance tends to underestimate the true rates of water transport (Riisgård and Møhlenberg, 1979). It therefore seems a more likely conclusion that the differences obtained in rates of water transport, as measured by the two methods, reflect the underestimate of the clearance technique.

In Ciona intestinalis and Ascidiella aspersa the exponent $b$ in the allometric equation $F=a W_{\text {total }}^{b}$ was 0.84 and 1.05 , respectively. Constant filtration rate per unit area of pharynx and isometric growth result in a value for $b$ of $2 / 3$ (or 0.67 ). The exponent of 0.84 found for $C$. intestinalis does not differ significantly from this value $(0.10<P<0.20)$, in contrast to the exponent of 1.05 found for $A$. aspersa, which is significantly different $(P<0.001)$. The high exponent found in $A$. aspersa can to a certain degree be accounted for by nonisometric growth of the test, which is growing according to the equation $W_{\text {test }}=0.448 W_{\text {total }}^{0.86}$ with the exponent being significantly different from 1 $(P<0.001)$. From the data of Hecht $(1916)$ the exponent $b$ in Ascidia atra has been calculated to be 0.87 $\left(r^{2}=0.84\right)$, in good agreement with our own findings. These high exponents are in contrast to the findings of Holmes (1973), who obtained exponents of 0.426 and 0.607 in Ascidiella aspersa, but, as suggested by Holmes, the exponent of 0.426 might have been due to disturbances of the animals. It would be of interest to study the allometric growth of the ascidian pharynx.

Both direct and indirect methods have been used for determining filtration rates in ascidians. In the direct methods, water transport has been determined by measuring the rate at which particles were 
sucked through a glass tube introduced into the oral aperture (Hecht, 1916); by the constant level method, where the total amount of water was sampled by means of a glass tube fixed into the exhalant aperture (Goldberg et al., 1951); by means of a dye-laden stream of sea water to match the inhalant water current (Holmes, 1973); by determining the rate of dyed water transported from one compartment to another via an animal attached to glass tubes (Kustin et al., 1974); or by means of a termistor to measure the exhalant water current (Fiala-Médioni, 1978a). In the in direct m e th od, water transport has been determined from the rates at which water was cleared of suspended particles (Jørgensen, 1949, 1952; Carlisle, 1966; FialaMédioni, 1973, 1974, 1978b, 1978c).

Figure 4 shows data from the literature on filtration rates in different species of ascidians together with our own results. (The data given by Kustin et al., 1974, are not included because of their great inconsistency). Direct methods involving glass tubes introduced into the ascidians' apertures are likely to disturb the animals, which may not behave normally or must pump against hydrostatic pressure; the difficulty in using indirect methods is mainly to prevent recirculation (i. e. to ensure effective mixing). In spite of these technical problems Figure 4 shows only moderate variation in data obtained by different techniques in different species. Apparently, Molgula manhattensis filters water at appreciably higher rates than do Ciona intestinalis and Ascidiella aspersa. This difference may be related to a folded pharynx in $M$. manhattensis, increasing the area of the water transporting structure.

The indirect method used in this study has proved to be suitable for accurate measurements of the filtration rate in undisturbed ascidians. Our values agree with the values obtained by Fiala-Médioni (1978a) in undisturbed ascidians in nature, using a termistor technique to measure the exhalant water current. These values presumably express the capacity for transporting water in undisturbed ascidians, and the work of Fiala-Médioni indicates that this capacity is normally fully exploited in nature.

Acknowledgements. Our warmest thanks are due to Cand. Scient. F. Mohlenberg, who participated in the preliminary investigations of this work, before he unfortunately had to leave the team. We are very grateful to the Marine Biological Laboratory, Helsinger, and to the Institute of Ecology and Genetics, University of Ârhus, for provision of room and facilities at Helsingør and at the Biological Station, Rønbjerg, respectively. Finally we would like to thank Professor C. Barker Jørgensen, August Krogh Institute, University of Copenhagen, for critically reading the manuscript.

\section{LITERATURE CITED}

Carlisle, D. B. (1966). The ciliary current of Phallusia (Ascidiacea) and the squirting of sea squirts. J. mar. biol Ass. U. K., 46, 125-127

Coughlan, J. (1969). The estimation of filtration rate from the clearance of suspensions. Mar. Biol., 2, 356-358.

Fiala-Médioni, A. (1973). Ethologie alimentaire d'invertébrés benthiques filtreurs (ascidies). I. Dispositif expérimental. Taux de filtration et de digestion chez Phallusia mammillata. Mar. Biol., 23, 137-145.

Fiala-Médioni, A. (1974). Ethologie alimentaire d'invertébrés benthiques filtreurs (ascidies). II. Variations des taux de filtration et de digestion en fonction de l'espèce. Mar. Biol., 28, 199-206.

Fiala-Médioni, A. (1978a). Filter-feeding ethology of benthic invertebrates (Ascidians). III. Recording of water current in situ-Rate and rhythm of pumping. Mar. Biol., 45, 185-190.

Fiala-Médioni, A. (1978b). Filter-feeding ethology of benthic invertebrates (Ascidians). IV. Pumping rate, filtration, filtration efficiency. Mar. Biol., 48, 243-249.

Fiala-Médioni, A. (1978c). Filter-feeding ethology of benthic invertebrates (Ascidians). $V$ Influence of temperature on pumping, filtration and digestion rates and rhythms in Phallusia mammillata. Mar. Biol., 48, 251-259.

Goldberg, E. D., McBlair, W. and Taylor, K. M. (1951). The uptake of vanadium by tunicates. Biol. Bull. mar. biol. Lab., Woods Hole, 101, 84-94.

Hecht, S. (1916). The water current produced by Ascidia atra Lesueur. J. exp. Zool., 20,429-434

Holmes, N. (1973). Water transport in the ascidians Styela clava Herdman and Ascidiella aspersa (Müller). J. exp. mar. Biol. Ecol., 11, 1-13

Jorgensen, C. B. (1949). Feeding rates of sponges, lamellibranchs and ascidians. Nature, Lond., 163, 912.

Jørgensen, C. B. (1952). On the relation between water transport and food requirements in some marine filter feeding invertebrates. Biol. Bull. mar. biol. Lab., Woods Hole, 103, $356-363$

Jorgensen, C. B. (1966). Biology of suspension feeding. Int. Ser. Monogr. pure appl. Biol. (Zoology), 27, 1-357.

Jorgensen, C. B. and Goldberg, E. D. (1953): Particle filtration in some ascidians and lamellibranchs. Biol. Bull mar biol. Lab., Woods Hole, 105, 477-489.

Kustin, K., Laad, K. V., McLeod, G. C. and Toppen, D. L. (1974): Water transport rates of the tunicate Ciona intestinalis. Biol. Bull. mar. biol. Lab., Woods Hole, 147, 608-617.

Mohlenberg, F. and Riisgård, H. U. (1978). Efficiency of particle retention in thirteen species of suspension feeding bivalves. Ophelia, 17, 239-246.

Mohlenberg, F. and Riisgård, H. U. (1979). Filtration rate, using a new indirect technique, in thirteen species of suspension feeding bivalves. Mar. Biol. (in press).

Riisgård, H. U. (1977). On measurements of the filtration rates of suspension feeding bivalves in a flow system. Ophelia, $16,167-173$.

Riisgård, H. U. and Møhlenberg, F. (1979). An improved automatic recording apparatus for determining the filtration rate of Mytilus edulis as a function of size and algal concentration. Mar. Biol., 52, 61-67.

Werner, E. and Werner, B. (1954). Über den Mechanismus des Nahrungserwerbs der Tunicaten, speciell der Ascidien. Helgoländer wiss. Meeresunters., 5, 57-92. 